\title{
What is the essential neurological examination?
}

\section{0 que é essencial no exame neurológico?}

\author{
Marco A. Lima1, Péricles Maranhão-Filho²
}

\begin{abstract}
In order to determine which aspects would be essential to the neurological examination (NE) in a given specific situation (a patient referred with a potential neurological complaint, but the history suggests that a neurological problem is unlikely), we presented the same questionnaire used by Moore and Chalk in Canada to 19 neurologists in Rio de Janeiro, Brazil. We considered significant aspects of NE, whose average responses were greater than or equal to 3.5: visual fields, fundoscopy, pursuit eye movements, facial muscle power testing, gait, pronator drift or rapid arm movement in upper limbs, finger-nose, tone in arms and legs, five tendon reflexes, and plantar responses. We concluded that, despite geographical and economical differences between Brazil and Canada, neurologists from both countries agree about the essential NE in the proposed scenario.
\end{abstract}

Key words: neurologic examination, neurosemiology, neurological complaint.

\section{RESUMO}

Visando determinar quais aspectos do exame neurológico (EN) seriam essenciais em uma situação específica (paciente com queixa neurológica, mas cuja história sugere ser improvável um problema neurológico), apresentou-se o mesmo questionário utilizado por Moore e Chalk no Canadá a 19 neurologistas do Rio de Janeiro, Brasil. Foram considerados os aspectos significativos do EN com pontuação igual ou superior a 3,5: campo visual, fundoscopia, movimentos de perseguição ocular, mímica facial, marcha, desvio pronador ou movimentos rápidos dos membros superiores, prova dedo-nariz, tônus nos membros superiores e inferiores, cinco reflexos tendinosos e reflexo plantar. Concluiu-se que, apesar de diferenças geográficas e econômicas entre Brasil e Canadá, neurologistas de ambos os países concordam sobre o exame neurológico essencial no cenário proposto.

Palavras-Chave: exame neurológico, neurossemiologia, queixa neurológica.

Many clinicians consider the neurological examination (NE) the most difficult and intriguing aspect of semiology. A common complaint is how to perform an excessive number of complex maneuvers in order to obtain clinical relevant information.

In 2009, Frazer Moore and Colin Chalk ${ }^{1}$ published the results of an interesting study called "The Essential Neurological Examination". In an early part of their work, they elected to investigate how neurologists use NE when faced with a common clinical situation: a patient referred with a potential neurological complaint in which the history suggests that a neurological problem is in fact unlikely, and the NE is being used to confirm that the patient is neurologically normal. Such researchers asked 19 McGill University neurologists to consider this scenario, and then asked them to state how likely they would be to use each of the 46 items of a reasonably complete NE. As an external validation, 38 neurologists across Canada and 168 students from McGill Medical School in a range of practice settings were asked to rate the $46 \mathrm{NE}$ elements, using the same scenario and rating scale. This study sought to evaluate how a group of neurologists based in Rio de Janeiro, Brazil, would use NE in the same scenario by Moore and Chalk's study.

\section{METHODS}

In order to investigate how experienced neurologists use the NE, we hypothesized a common clinical scenario: a patient referred with a potential neurological complaint, but the history suggests that a neurological problem is in fact unlike, and the $\mathrm{NE}$ is being used to confirm that the patient is neurologically normal.

${ }^{1}$ MD PhD, Department of Neurosurgery, National Institute of Cancer (INCA); Laboratory of Clinical Research in Neuroinfections, Instituto de Pesquisa Clínica Evandro Chagas, Fundação Oswaldo Cruz (IPEC-Fiocruz), Rio de Janeiro RJ, Brazil;

${ }^{2} \mathrm{MD}$ PhD, Department of Neurosurgery, National Institute of Cancer (INCA); Department of Neurology, Universidade Federal do Rio de Janeiro (UFRJ), Rio de Janeiro RJ, Brazil.

Correspondence: Marco A. Lima; Avenida Alexandre Ferreira 420 / apto. 403; 22470-220 Rio de Janeiro RJ - Brasil; E-mail: mlima@inca.gov.br

Conflict of interest: There is no conflict of interest to declare.

Received 27 February 2012; Received in final form 29 June 2012; Accepted 06 July 2012 
We presented the same questionnaire used in the Canadian study (Table 1), and asked 19 neurologists from Rio de Janeiro, Brazil, to score each item using a four-point scale, in which four indicates "I would always include this"; three "> $80 \%$ of the time"; two "sometimes, but less

Table 1. Items of the neurological questionnaire.

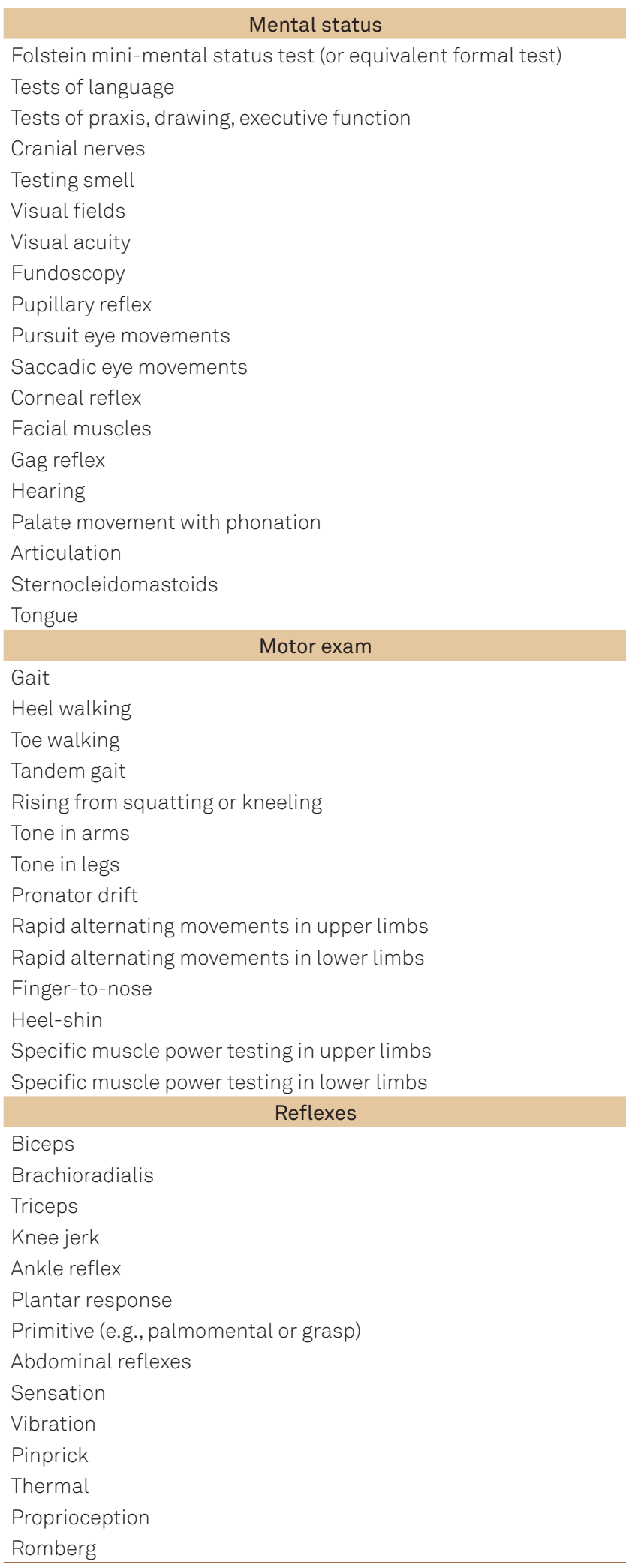

than $80 \%$ "; and one was "never or almost never needs to be included".

Among the 19 Brazilian neurologists, 13 were general neurologists and 6 spent most of their practice time in specialty clinics (headache, demyelinating diseases, dementia, and epilepsy). Four neurologists had from one to ten years of practice; six had between 11 to 20 years and 9 had more than 21 years.

Mean and standard deviations for each of the $46 \mathrm{NE}$ elements were computed, and then participants were asked to repeat their scoring of the NE elements, however, at this time, taking into consideration the group mean scores. We used the Delphi procedure ${ }^{2}$, which is based on the premise that pooling opinions enhances individual judgments and accurately captures the views of a group, and compared our results with those obtained by Canadian neurologists. NE items that were given scores greater than 3.5 were considered the most relevant.

\section{RESULTS}

Twenty items of the questionnaire had a mean score greater than 3.5 (Table 2), 17 of which were in agreement with the results of the Canadians. The differences were that Brazilian neurologists more often test light touch, while

Table 2. Items of the neurological examination rated 3.5 or greater.

\begin{tabular}{|c|c|c|}
\hline $\begin{array}{l}\text { Brazilian } \\
\text { neurologists }\end{array}$ & McGill neurologists & $\begin{array}{c}\text { Canadian } \\
\text { neurologists }\end{array}$ \\
\hline \multirow[t]{2}{*}{ Fundoscopy } & & Fundoscopy \\
\hline & Visual fields & Visual fields \\
\hline Pursuit EOM & Pursuit EOM & Pursuit EOM \\
\hline Pupillary light reflex & & Pupillary light reflex \\
\hline Facial muscles & Facial muscles & Facial muscles \\
\hline Gait & Gait & Gait \\
\hline \multicolumn{3}{|l|}{ Tongue } \\
\hline \multicolumn{3}{|c|}{ Pronator drift } \\
\hline RAM upper & & RAM upper \\
\hline Finger-nose & Finger-nose & Finger-nose \\
\hline Tone arms & & Tone arms \\
\hline Tone legs & & Tone legs \\
\hline Power arms & & Power arms \\
\hline Power legs & & Power legs \\
\hline Biceps reflex & Biceps reflex & Biceps reflex \\
\hline $\begin{array}{l}\text { Brachioradialis } \\
\text { reflex }\end{array}$ & $\begin{array}{c}\text { Brachioradialis } \\
\text { reflex }\end{array}$ & $\begin{array}{c}\text { Brachioradialis } \\
\text { reflex }\end{array}$ \\
\hline Triceps reflex & Triceps reflex & Triceps reflex \\
\hline Patellar reflex & Patellar reflex & Patellar reflex \\
\hline Achilles reflex & Achilles reflex & Achilles reflex \\
\hline Plantar reflex & Plantar reflex & Plantar reflex \\
\hline \multicolumn{3}{|l|}{ Romberg } \\
\hline \multicolumn{3}{|l|}{ Light touch } \\
\hline & & Pinprick \\
\hline
\end{tabular}

EOM: extraocular movement; RAM: rapid arm movement. 
Canadians test pinprick; Brazilians examine tongue and perform Romberg test but Canadians check visuals fields more frequently. McGill neurologists rated only 12 items higher than 3.5 and almost all of them were in agreement with Brazilian neurologists, except for visual fields and pronator drift. However, if we consider a score higher than 3 instead, all of the items are contemplated by both groups.

\section{DISCUSSION}

Contemporary neurological practice demands greater efficiency and effectiveness. The NE is a curious compendium of maneuvers; many of these are named, some have multiple names, and many are not named ${ }^{3}$. Neurologists tailor their own examination practices to judgments of situational utility, a skill that cannot be routinely expected of generalists. Unfortunately, regarding the neurological teaching and learning, many professors create expectations for performance of complete examinations that they usually do not perform or need $^{4,5}$. Clearly, some tests are more marginal than others, and in a general situation regarding a specificity, it is expected that neurology professors will differ in their choices for pruning the traditional examination ${ }^{6,7}$.

The NE varies widely by disorder (e.g., dementia versus low back pain), and the examination is directed by the history. Thus, there is no single, essential NE. The actual elements identified as being essential would vary depending on the patient's complaint ${ }^{8}$. Furthermore, the proposed scenario is frequently observed in neurology clinics worldwide. Interestingly, despite geographical and economical differences between Brazil and Canada that result in distinct prevalence of neurological diseases, there was a high rate of agreement among neurologists of these two countries, therefore there is probably a perception that some neurological maneuvers constitute a core of the NE and are performed independently of the background. Rational modification of the NE does not imply that it is becoming obsolete, but rather that neurologists should assist medical students and residents to develop greater competency in a streamlined exam, emphasizing high-yield aspects ${ }^{4}$.

Our results showed that, for neurologists from Rio de Janeiro, the most important aspects of NE were basically the same from Canada: visual fields, fundoscopy, pursuit eye movements, facial muscle power testing, gait, pronator drift or rapid arm movement in upper limbs, finger-nose, tone in arms and legs, five tendon reflexes, and plantar responses. The major aspects of the NE were increased by light touch, Romberg sign, and tongue examination.

In conclusion, this was a pilot study, which showed no significant differences between the NE features used by 19 neurologists from Rio de Janeiro, Brazil, when compared to those used by Canadian ones, when both groups faced the same and common situations. The authors are fully aware that the number of participating neurologists is small and, in the future, this study could also be expanded to other Brazilian cities.

\section{ACKNOWLEDGMENTS}

The authors are in debit with the 19 neurologists who agreed to participate in this study and thank Mrs. Raquel de Oliveira for the assistance with the statistical analysis.

\section{References}

1. Moore FG, Chalk C. The essential neurologic examination: what should medical students be taught? Neurology 2009;72:2020-2203.

2. Linstone HA, Turoff M. The Delphi method: techniques and applications 2002. [Internet] [cited 2011 Dec 04]. Available at: http:// is.njit.edu/pubs/delphibook/

3. Louis ED. The neurological examination (with an emphasis on its historical underpinnings). Preface. Sem Neurol 2002;22:2.

4. GlickTH. Toward a more efficient and effective neurologic examination for the 21st century. Eur J Neurol 2005;12:994-997.

5. Chalk C. How should we teach the neurological examination to medical students? Course 1EP001. Syllabi CD-ROM - AAN; 2010.

6. Maranhão-Filho PA, Maranhão ET, Silva MM, Lima MA. Rethinking the neurological examination I Static balance assessment. Arq Neuropsiquiatr 2011;69:954-958.

7. Maranhão-Filho PA, Maranhão ET, Lima MA, Silva MM. Rethinking the neurological examination II Dynamic balance assessment. Arq Neuropsiquiatr 2011;69:959-963.

8. Meador KJ, Moore F, Chalk C. The essential neurologic examination: what should medical students be taught? Neurology 2009;73; 2133-2134. 